\title{
HEMATOLOGICAL STUDIES IN HYPOTHYROIDISM FOLLOWING TOTAL THYROIDECTOMY ${ }^{1}$
}

\author{
By BEATRICE STERN AND MARK D. ALTSCHULE \\ (From the Medical Research Laboratories of the Beth Israel Hospital and the Department of \\ Medicine, Harvard University Medical School, Boston)
}

(Received for publication June 16, 1936)

The frequent occurrence of mild anemia in myxedema has long been recognized $(1,2)$. The red blood cell count has usually been between $3,000,000$ and 4,500,000 per cubic millimeter with hemoglobin percentage occasionally as low as 60 per cent but most often approximating 75 per cent. There is less agreement concerning changes in white blood cell count, different authors describing leukocytosis, leukopenia, or a normal white count. It was felt that more precise data concerning the nature and extent of the blood changes could be obtained from the study of patients in whom hypothyroidism was developing under close observation. Accordingly, studies were made before and after total thyroidectomy in patients with chronic heart disease $(3,4,5)$. The blood counts, hemoglobin percentages, arterial oxygen capacities, and type and size of red and white blood cells in relation to changes in the basal metabolic rate during the development and control of hypothyroidism induced by total thyroidectomy are reported below. The effects of iron and of thyroid medication on the blood findings in postoperative hypothyroidism are also described.

\section{METHODS}

Red and white blood cell counts and hemoglobin estimations were made from capillary blood in a series of 40 patients at various levels of metabolism after total thyroidectomy. In nine additional patients more extensive hematological studies on venous blood were made before and at varying time intervals after total thyroidectomy; six of these patients were operated on for the relief of congestive heart failure and three for angina pectoris. In a further group of fifteen patients with previous congestive failure or angina pectoris, seventeen studies were done postoperatively on the venous blood. The preoperative studies were made a few days before operation when patients with congestive failure

1 This investigation was aided by a grant from the William W. Wellington Memorial Research Fund of Harvard University. showed minimal signs of decompensation and were in the best possible condition for operation; all postoperative studies were made a few weeks to three years following thyroidectomy in the absence of signs of congestive heart failure. In many instances, patients studied postoperatively were receiving doses of desiccated thyroid sufficient to prevent distressing symptoms of myxedema, basal metabolic levels of approximately -20 to -30 per cent being maintained (6).

Except in the preliminary studies, oxalated venous blood drawn without stasis from the patients in the postabsorptive state, was used for measurement of hemoglobin per cent and red and white blood cell counts. Icteric indices and hematocrit readings were estimated from the same samples of blood, a correction factor of 1.08 being applied to the hematocrit reading for the amount of oxalate used (7). Smears for Schilling index and measurements of mean cell diameter and for reticulocyte and platelet counts were made from capillary blood. Measurements of oxygen capacity were made on arterial blood drawn from the patients in the postabsorptive state.

Hemoglobin measurements were made by the Sahli method using a Sahli hemoglobinometer standardized so that 100 per cent hemoglobin corresponded to 20.9 volumes per cent oxygen capacity. The oxygen capacity was measured by the method of Van Slyke and Neill (8). Red and white blood cell counts were done in duplicate using the same counting chamber and cover slip throughout. Pipettes and counting chamber had been calibrated by the United States Bureau of Standards. The reticulocytes and platelets were estimated by the method of Dameshek (9). A calibrated micrometer eye-piece was used for measuring mean cell diameters; mean corpuscular volumes were calculated from the hematocrit per cent and the red blood cell count. Icteric indices were estimated by the method of Davis (10). Measurements of basal metabolic rate were made in duplicate with a Collins-Benedict-Roth apparatus and calculated according to the Aub-DuBois normal standards (11).

\section{RESULTS}

The preliminary studies on capillary blood showed a decrease in the hemoglobin percentage and the red blood cell count at low levels of basal metabolism following total thyroidectomy (Table I). This finding was more striking in patients operated upon for the relief of congestive heart 
TABLE I

Average results of postoperative blood counts on capillary blood

\begin{tabular}{|c|c|c|c|c|c|}
\hline $\begin{array}{c}\text { Deviation } \\
\text { from normal } \\
\text { basal } \\
\text { metabolic } \\
\text { rate }\end{array}$ & $\begin{array}{l}\text { Num- } \\
\text { ber of } \\
\text { counts }\end{array}$ & $\begin{array}{l}\text { Hemo- } \\
\text { globin } \\
\text { (Sahli) }\end{array}$ & $\begin{array}{c}\text { Red } \\
\text { blood } \\
\text { cells }\end{array}$ & $\begin{array}{l}\text { Num- } \\
\text { ber of } \\
\text { counts }\end{array}$ & $\begin{array}{l}\text { White } \\
\text { blood } \\
\text { cells }\end{array}$ \\
\hline per cent & & per cent & per cu.mm. & & $\begin{array}{c}\text { per } \\
\text { cu.mm. }\end{array}$ \\
\hline
\end{tabular}

PATIBNTS WITH CONGESTIVE HEART FAILURE

\begin{tabular}{l|r|r|r||r|r}
\hline+2 to -10 & 6 & 93 & $4,367,000$ & 3 & 9,250 \\
-10 to -20 & 9 & 90 & $4,387,000$ & 2 & 10,400 \\
-20 to -30 & 11 & 87 & $3,948,000$ & 4 & 7,662 \\
-30 to -40 & 11 & 80 & $3,874,000$ & 7 & 7,050 \\
\hline
\end{tabular}

PATIENTS WITH ANGINA PECTORIS

\begin{tabular}{r||r|r|r|r|r}
\hline 0 to -10 & 5 & 89 & $4,114,000$ & 2 & 10,800 \\
-10 to -20 & 9 & 95 & $4,685,000$ & 4 & 8,025 \\
-20 to -30 & 13 & 94 & $4,351,000$ & 3 & 6,066 \\
-30 to -40 & 12 & 89 & $4,168,000$ & 5 & 7,425 \\
\hline
\end{tabular}

failure than in those operated upon for the relief of angina pectoris. The changes in hemoglobin and red blood cell count were paralleled, in general, by changes in oxygen capacity; twenty-three de-

TABLE II

Correlation between arterial oxygen capacity and basal metabolic rate following total thyroidectomy

\begin{tabular}{|c|c|c|}
\hline Case & $\begin{array}{c}\text { Deviation from } \\
\text { normal basal } \\
\text { metabolic rate }\end{array}$ & $\begin{array}{l}\text { Oxygen } \\
\text { capacity }\end{array}$ \\
\hline W. M. & $\begin{array}{c}\text { per cent } \\
+1 \\
-31\end{array}$ & $\begin{array}{c}\text { volumes per cent } \\
\qquad \begin{array}{c}20.8 \\
16.5\end{array}\end{array}$ \\
\hline A. $\mathbf{R}$. & $\begin{array}{r}-2 \\
-34\end{array}$ & $\begin{array}{l}20.8 \\
17.7\end{array}$ \\
\hline E. P. & $\begin{array}{l}-23 \\
-20\end{array}$ & $\begin{array}{l}17.1 \\
18.1\end{array}$ \\
\hline M. W. & $\begin{array}{r}-7 \\
-19\end{array}$ & $\begin{array}{l}21.9 \\
18.3\end{array}$ \\
\hline M. C. & $\begin{array}{l}-24 \\
-34\end{array}$ & $\begin{array}{l}18.4 \\
15.7\end{array}$ \\
\hline E. M. & $\begin{array}{r}-4 \\
-34\end{array}$ & $\begin{array}{l}22.0 \\
20.7\end{array}$ \\
\hline G. M. & $\begin{array}{r}-6 \\
-11 \\
-24\end{array}$ & $\begin{array}{l}23.9 \\
22.5 \\
21.7\end{array}$ \\
\hline G. B. & $\begin{array}{r}-9 \\
-15\end{array}$ & $\begin{array}{l}19.8 \\
17.9\end{array}$ \\
\hline M. H. & $\begin{array}{r}+1 \\
-7 \\
-21\end{array}$ & $\begin{array}{l}22.6 \\
22.5 \\
20.1\end{array}$ \\
\hline T. K. & $\begin{array}{r}-1 \\
-11 \\
-28\end{array}$ & $\begin{array}{l}21.6 \\
19.7 \\
18.9\end{array}$ \\
\hline
\end{tabular}

terminations of arterial oxygen capacity done on ten patients before and after total thyroidectomy showed a diminution of oxygen capacity as the basal metabolic rate decreased (Table II).

Hematological studies made before and at various time intervals after operation in six patients operated on for the relief of congestive failure revealed a lowering of the hemoglobin per cent, the hematocrit reading, the red and white cell and platelet counts and an increase in the mean corpuscular volume and mean cell diameter when the basal metabolic rate had fallen to low levels (Table III). In Case T. K. (Table III), who showed a typical drop in basal metabolic rate from -1 per cent preoperatively to -29 per cent three months after operation, the red blood cell count decreased from $4,450,000$ to $3,760,000$, the hemoglobin per cent from 90 to 87 , the white blood cell count from 5,700 to 3,050 , the hematocrit per cent from 45.3 to 38.9 , the platelet count from 293,000 to 289,000 ; the mean corpuscular volume showed a rise from 101 to 103.4 , and the mean cell diameter increased from 7.7 to 8.0. Six months after operation, although the basal metabolic rate was essentially the same $(-28$ per cent), the blood showed further change. These data are graphically presented in Figure 1. Data obtained in eleven postoperative studies on ten other patients operated upon for the relief of congestive failure corroborate the above findings (Table III). In Table IV, the data obtained postoperatively in all the patients operated upon for congestive failure are divided into four groups representing various levels of basal metabolism, and the average values for each group are recorded. Despite considerable individual variation, a lowering of the average values for hemoglobin, red and white blood counts, hematocrit per cent, and platelet count, and an increase in the values for mean corpuscular volume and mean cell diameter were evident as the basal metabolic rate decreased (Figure 2). In general, the corpuscular volume increased more than the cell diameter, so that the red blood cells apparently became thicker.

In one patient (Case E. B., Table III) a hypochromic anemia due to frequent hemoptyses was present before thyroidectomy. Two months after operation the hemoglobin was 101 per cent and the 







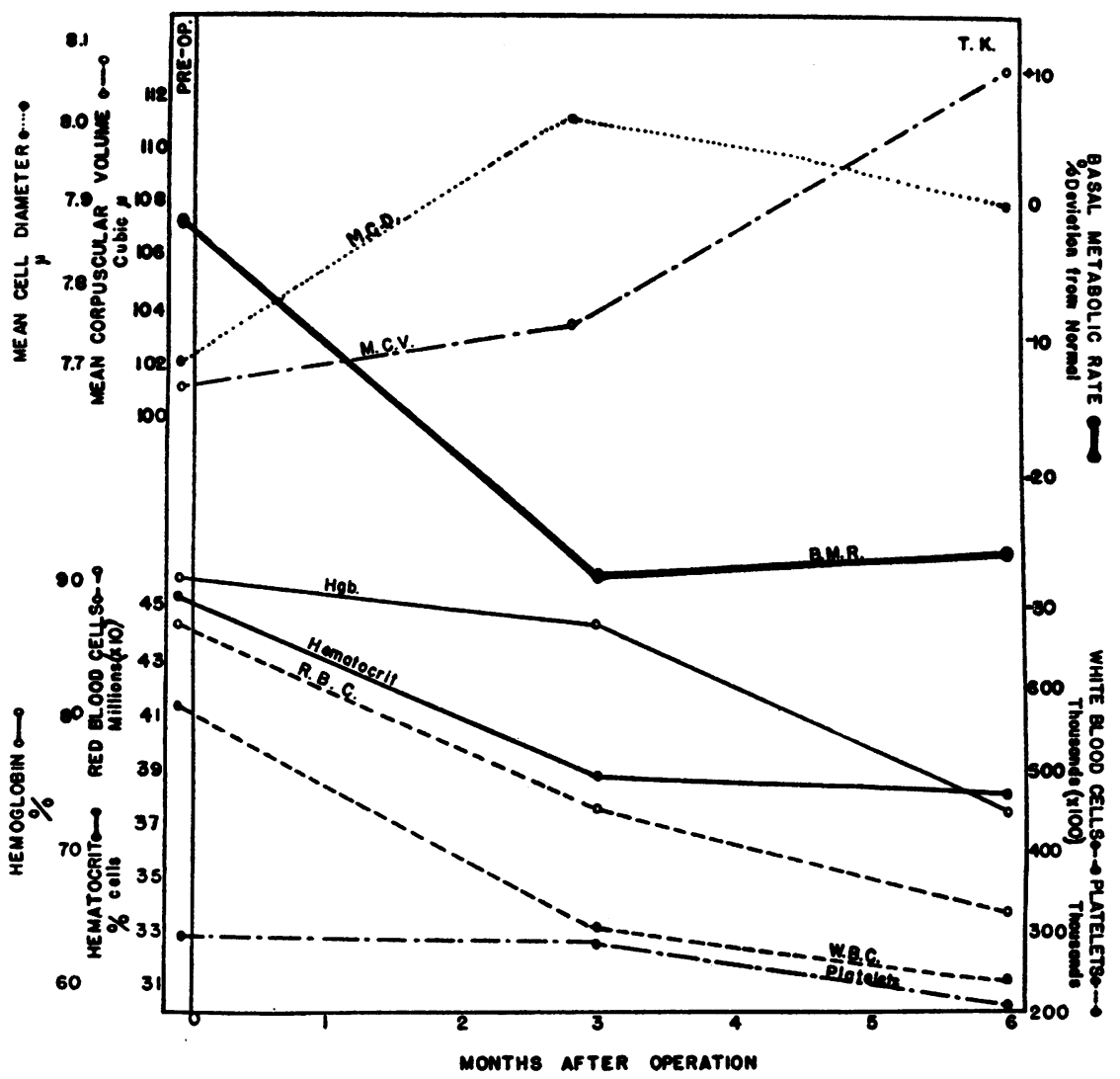

Fig. 1. Relation between Time of Onset of Hypothyromism and of Changes in Blood Picture Following Total Thyroidectomy (Case T. K.).

TABLE IV

Average results of postoperative studies in hematology. Studies on venous blood

\begin{tabular}{|c|c|c|c|c|c|c|c|c|}
\hline $\begin{array}{l}\text { Deviation from } \\
\text { normal basal } \\
\text { metabolic rate }\end{array}$ & $\begin{array}{l}\text { Number } \\
\text { of } \\
\text { studies }\end{array}$ & $\begin{array}{l}\text { Hemo- } \\
\text { globin } \\
\text { (Sahli) }\end{array}$ & Red blood cells & $\begin{array}{l}\text { White } \\
\text { blood } \\
\text { cells }\end{array}$ & Hematocrit & Platelets & $\begin{array}{c}\text { Mean } \\
\text { corpuscular } \\
\text { volume }\end{array}$ & $\begin{array}{c}\text { Mean } \\
\text { cell } \\
\text { diameter }\end{array}$ \\
\hline per cent & & per cent & per cu.mm. & per cu.mm. & per cent & per cu.mm. & cu. $\mu$ & $\mu$ \\
\hline \multicolumn{9}{|c|}{ PATIENTS WITH CONGESTIVE FAILURE } \\
\hline $\begin{array}{r}\text { *Preop. level } \\
0 \text { to }-10 \\
-10 \text { to }-20 \\
-20 \text { to }-30 \\
-30 \text { to }-40\end{array}$ & $\begin{array}{l}6 \\
2 \\
6 \\
7 \\
3\end{array}$ & $\begin{array}{r}89 \\
100 \\
86 \\
77 \\
80\end{array}$ & $\begin{array}{l}4,630,000 \\
4,927,000 \\
4,402,000 \\
3,534,000 \\
3,593,000\end{array}$ & $\begin{array}{l}6,755 \\
8,563 \\
6,908 \\
5,086 \\
5,550\end{array}$ & $\begin{array}{l}45.2 \\
47.0 \\
42.3 \\
36.0 \\
35.5\end{array}$ & $\begin{array}{l}366,000 \\
425,000 \\
331,000 \dagger \\
235,000 \\
293,000\end{array}$ & $\begin{array}{r}96 \\
96 \\
94 \\
102 \\
99\end{array}$ & $\begin{array}{l}7.7 \\
7.4 \\
7.4 \\
7.7 \\
7.5\end{array}$ \\
\hline \multicolumn{9}{|c|}{ PATIENTS WITH ANGINA PECTORIS } \\
\hline $\begin{array}{l}\text { Preop. level } \\
-10 \text { to }-20 \\
-20 \text { to }-30 \\
-30 \text { to }-40\end{array}$ & $\begin{array}{l}3 \\
3 \\
4 \\
1\end{array}$ & $\begin{array}{l}88 \\
90 \\
88 \\
88\end{array}$ & $\begin{array}{l}4,489,000 \\
4,630,000 \\
3,947,000 \\
3,950,000\end{array}$ & $\begin{array}{l}6,380 \\
8,117 \\
5,256 \\
6,825\end{array}$ & $\begin{array}{l}41.3 \\
42.3 \\
41.6 \\
44.0\end{array}$ & $\begin{array}{l}194,000 \ddagger \\
400,000 \ddagger \\
251,000 \\
253,000\end{array}$ & $\begin{array}{r}92 \\
92 \\
107 \\
110\end{array}$ & $\begin{array}{l}7.5 \\
7.8 \\
7.6 \\
7.2\end{array}$ \\
\hline
\end{tabular}

* The range of preoperative basal metabolic rate in all patients was from +11 to -9 per cent.

$\dagger$ Represents average of 5 observations.

$\ddagger$ Represents average of 2 observations. 


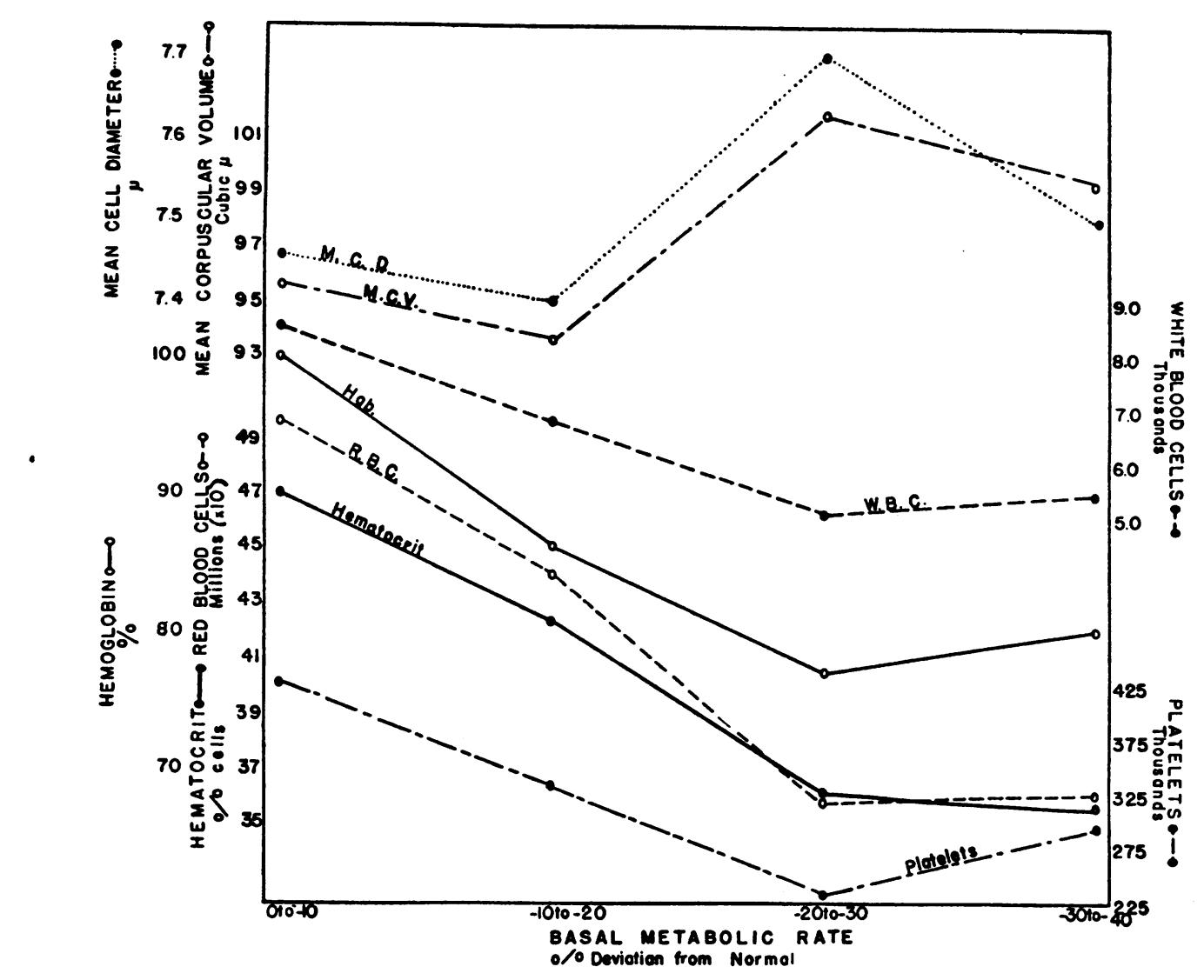

Fig. 2. Relationship between Changes in Hematology and Changes in Basal Metabolic Rate Following Total Thyroidectomy.

Summary of average results in eighteen patients operated on for congestive heart failure.

red blood cell count, 5,100,000. Subsequently, as hypothryoidism persisted, a normocytic anemia developed.

Studies before and at various time intervals after thyroidectomy in three patients operated on for the relief of angina pectoris revealed no significant hematological changes in two of these (Table III). The third patient developed a slight anemia when the basal metabolic rate had dropped from -7 per cent preoperatively to -24 per cent postoperatively. Four additional studies done postoperatively only on four other patients operated on for angina pectoris confirmed these findings; only two of these patients showed evidence of slight anemia at basal metabolic rates of -29 per cent and -32 per cent (Table III). The average results of the studies in patients operated on for angina pectoris are recorded in Table IV.
Although the white blood cell count in many instances was significantly decreased when hypothyroidism had developed, no striking deviations from the normal distribution of the various cell types were observed in differential and Schilling index counts in any of the patients studied (Table III). The red blood cells appeared normal in size and shape; there was no achromia. The reticulocyte counts varied within normal limits. Icteric indices ranged from 2 to 12 ; values above 8 were encountered in only three patients operated on for congestive heart failure and in only one patient operated on for angina pectoris; all values were within the normal limits.

Studies of the hemoglobin per cent, red blood cell count, and white blood cell count were made on four patients with postoperative hypothyroidism before the institution of iron therapy and again after patients had been receiving this medi- 
TABLE V

Effect of medication on anemia of hypothyroidism

\begin{tabular}{|c|c|c|c|c|c|}
\hline Case & $\begin{array}{l}\text { Deviation } \\
\text { from normal } \\
\text { basal meta- } \\
\text { bolic rate }\end{array}$ & $\begin{array}{c}\text { Hemoglobin } \\
\text { (Sahli) }\end{array}$ & $\begin{array}{l}\text { Red blood } \\
\text { cells }\end{array}$ & $\begin{array}{l}\text { White blood } \\
\text { cells }\end{array}$ & Medication \\
\hline G. F. & $\begin{array}{l}\text { per cent } \\
-27 \\
-29 \\
-29\end{array}$ & $\begin{array}{c}\text { per cent } \\
74 \\
72 \\
75\end{array}$ & $\begin{array}{l}\text { per cu.mm. } \\
3,435,000 \\
3,730,000 \\
3,405,000\end{array}$ & $\begin{array}{c}\text { per cu.mm. } \\
5,025 \\
4,850\end{array}$ & $\begin{array}{l}\text { Before medication. } \\
\text { Ferrous sulfate grains } 4,6 \text { i. d. for } 3 \text { weeks.* } \\
\text { Ferrous sulfate grains } 4,6 \text { i.d. for } 4 \text { weeks. }\end{array}$ \\
\hline L. B. & $\begin{array}{l}-29 \\
-27\end{array}$ & $\begin{array}{l}90 \\
94\end{array}$ & $\begin{array}{l}3,950,000 \\
4,150,000\end{array}$ & 5,000 & $\begin{array}{l}\text { Before medication. } \\
\text { Ferrous sulfate grains } 4,6 \text { i. d. for } 2 \text { months. }\end{array}$ \\
\hline S. L. & $\begin{array}{l}-27 \\
-32\end{array}$ & $\begin{array}{l}85 \\
78\end{array}$ & $\begin{array}{l}3,980,000 \\
3,520,000\end{array}$ & & $\begin{array}{l}\text { Before medication. } \\
\text { Reduced iron } 15 \text { grains t. i. d. for several months. }\end{array}$ \\
\hline H. W. & $\begin{array}{l}-23 \\
-17\end{array}$ & $\begin{array}{l}78 \\
85\end{array}$ & $\begin{array}{l}3,900,000 \\
4,140,000\end{array}$ & 8,050 & $\begin{array}{l}\text { Before medication. } \\
4 \text { grains iron } 4 \text { i. d. }\end{array}$ \\
\hline G. F. & $\begin{array}{l}-29 \\
-27\end{array}$ & $\begin{array}{l}75 \\
75\end{array}$ & $\begin{array}{l}3,405,000 \\
3,430,000\end{array}$ & 4,850 & $\begin{array}{l}\text { Before medication. } \\
\text { Thyroid grains } 1 / 20 \text { daily for } 1 \text { month. } \dagger\end{array}$ \\
\hline W. D. & $\begin{array}{l}-31 \\
-23\end{array}$ & $\begin{array}{l}80 \\
91\end{array}$ & $\begin{array}{l}3,865,000 \\
4,480,000\end{array}$ & & $\begin{array}{l}\text { Before medication. } \\
\text { Thyroid grains } 1 / 10 \text { daily for } 2 \text { months. }\end{array}$ \\
\hline
\end{tabular}

* Daily reticulocyte count for 2 weeks following institution of iron therapy. No reticulocytosis.

† Daily reticulocyte count for 1 month following institution of thyroid medication. No reticulocytosis.

cation for one month or longer. No significant changes were found even when large doses of iron were given (Table V). Daily reticulocyte counts in one patient for three weeks following iron medication showed no increase in reticulocytes.

Hematological studies and measurements of the basal metabolic rates were made on two patients receiving small doses of desiccated thyroid (Armour's) for the alleviation of the more severe symptoms of myxedema. Case G. F. who received $1 / 20$ th grain thyroid daily showed no change in hematology and no significant change in basal metabolic rate over a period of four weeks after starting medication. Daily reticulocyte counts on this patient for one month following the institution of thyroid therapy showed no reticulocyte response. Another patient, Case W. D., received 1/10th grain thyroid daily for two months; there was an increase in hemoglobin from 80 per cent to 91 per cent and an increase in red blood cell count from $3,865,000$ to $4,480,000$ per cubic millimeter of blood when the basal metabolism had risen from -31 per cent to -23 per cent (Table V).

\section{COMMENT}

The data in the present study demonstrate the development of a mild anemia in hypothyroidism following the total removal of the thyroid gland in man. When the basal metabolic rate had fallen to between -20 and -30 per cent, the average values found were 77 per cent hemoglobin and $3,534,000$ red cells per cubic millimeter of blood in patients operated on for the relief of congestive heart failure, and 88 per cent hemoglobin and $3,948,000$ red cells per cubic millimeter of blood in patients operated on for angina pectoris (Table IV). That the changes in the blood picture in patients with angina pectoris were not as striking as those in patients with congestive failure may be related to the fact that the majority of the subjects with angina had moderate degrees of pulmonary emphysema. The anemia in all patients after operation was at most moderate and usually only slight, the lowest values for hemoglobin and red blood count observed in the entire series being 71 per cent and 3,080,000 respectively (Table III). It should be noted that the patient with 71 per cent hemoglobin had a red blood cell count of $3,340,000$ and the patient with $3,080,000$ red cells per cubic millimeter of blood had a hemoglobin of 83 per cent. These observations are in harmony with reported findings in spontaneous myxedema in man and in hypothyroidism following experimental thyroidectomy in animals $(1,12,13,14,15,16)$. 
Significant changes in the blood picture following total thyroidectomy occur only at low levels of basal metabolism. Data in one patient (Case T. K., Table III) indicate that the hemoglobin per cent and red blood cell count may continue to diminish slightly after the basal metabolic rate has become established at a low level. That more marked degrees of anemia were not encountered may be related to the fact that severe myxedema was not allowed to persist; small doses of desiccated thyroid were administered to alleviate the distressing symptoms of marked hypothyroidism, the basal metabolic rate being maintained at a level of between -26 per cent and -32 per cent in most instances.

None of the patients studied showed symptoms or physical signs which could be ascribed to the anemia. Sore tongue and paresthesias or objective neurological changes in the extremities were never encountered. The pallor and sensitivity to cold present in most cases in which the basal metabolic rate was below -20 per cent were probably due to hypothyroidism as such. Elevation of the pulse rate was not observed in the cases of this series. Such dyspnea as was exhibited by the patients studied here was undoubtedly associated with their heart disease, and was invariably milder than before operation. Several observers have reported an increase in cardiac output $(17,18)$ or an accelerated velocity of blood flow (19) both indicative of increased cardiac work, in patients with low red blood cell counts and hemoglobin percentages. However, the decrease in oxygen carrying capacity of the blood in such instances was always more severe than that found in the patients studied here. Moreover, it has been shown that the cardiac output after total thyroidectomy is not influenced by the mild degrees of anemia which accompany a fall in basal metabolic rate to between -20 per cent and -30 per cent. It would appear, therefore, that the anemia which develops following total thyroidectomy is not clinically important and places no demonstrable burden on the cardiovascular system.

The progressive increase in color index, mean cell diameter, and mean corpuscular volume during the development of hypothyroidism indicate that the anemia tends toward the macrocytic hyperchromic type. The increase in thickness of the red blood cells is somewhat greater than the increase in diameter. Kunde, Green, and Burns (16), and later Sharpe and Bisgard (20), in their studies on myxedematous rabbits, also observed a high color index and an increased diameter of the red blood cell. In one case of anemia of myxedema studied by Minot in 1921 (21), the size of the red blood cells was found to be normal and the color index slightly decreased. It is of interest that in one of the patients with mitral stenosis (Case E. B.), a hypochromic anemia, which was present before total thyroidectomy, cleared up entirely after operation when the repeated hemoptyses causing the anemia ceased. The red blood cell count and hemoglobin were $5,100,000$ and 101 per cent respectively two months after operation. One month later, the blood showed evidences of a normocytic anemia.

The cause of the anemia of myxedema has not yet been established. Studies by other investigators of the effect of various medications have yielded data which support the concept of a decrease in hematopoiesis due to insufficient circulating thyroid hormone and not to a lack of Castle's anti-pernicious anemia factor or of iron. Baldridge and Greene (22) found no response to liver therapy in eleven patients with anemia of myxedema. Means, Lerman, and Castle (23) reported a case in which pernicious anemia, myxedema, and anemia of myxedema coexisted. The reticulocytosis after liver therapy was followed by a second reticulocyte response when thyroid medication was administered. Lerman and Means (24) felt that an iron deficiency was at least partly responsible for the anemia present in a few of their patients with spontaneous myxedema. It is, however, not entirely clear from their data that the iron deficiency was due to the hypothyroidism as such. In the present study iron deficiency was shown to be of no importance as an etiological factor in the anemia which developed after total thyroidectomy; four patients given moderate or large doses of iron showed no reticulocytosis and no significant changes in the blood picture.

Many observers have agreed that the anemia of myxedema is due to decreased formation of blood caused by lack of thyroid hormone. Minot wrote in 1921, "treat with active thyroid to clear up the myxedema and the anemia will improve con- 
comitantly" (21). MacKenzie (14), and Stone (25), and Lerman and Means (24), have reported complete disappearance of the anemia of myxedema following appropriate thyroid medication. Lisser and Anderson (15) reported that under thyroid medication the improvement in the blood picture paralleled the restoration of the basal metabolic rate to normal. Kunde, Green and Burns (16) found a reticulocyte response of 4 to 10 per cent in hypothyroid animals following thyroid feeding.

The findings in the present study were in accord with those of other investigators. The response to minimal doses of thyroid was studied in two patients; in one instance, Case G. F. (Table V), $1 / 10^{\text {th }}$ grain desiccated thyroid was administered every second day with no significant change in basal metabolic rate or hematological findings. In another patient, Case W. D. (Table V), who was receiving $1 / 10^{\text {th }}$ grain thyroid daily a rise in basal metabolic rate from -31 per cent to -23 per cent occurred, and concomitantly there was an improvement in the anemia. These data support the concept that the anemia of myxedema is due to decreased bone marrow function associated with diminished circulating thyroid hormone.

Other evidences of diminished function of bone marrow were seen in the white blood cell and platelet counts. The white blood cell count was diminished when the basal metabolic rate decreased after total thyroidectomy; the average of seven values obtained in the patients operated on for congestive heart failure was 5,086 per cubic millimeter of blood when the basal metabolic rate was between -20 and -30 per cent. These data confirm the findings of Minot (21), Krantz (26), and Kocher (27) in spontaneous myxedema. However, other authors have found a normal (2, 25) or even an increased white blood cell count (12) in spontaneous myxedema. The findings of a decreased platelet count in many patients at low levels of metabolism after total thyroidectomy accords with the findings of Minot (21) in one patient with spontaneous myxedema. The lowered platelet count was in no case associated with purpuric manifestations.

Although diminished hematopoiesis occurs in hypothyroidism, the bone marrow retains its power to respond normally to stimuli. Unpublished results of studies made in this clinic show that patients with the anemia of hypothyroidism following total thyroidectomy can respond to infection or anoxemia of congestive failure by a normal increase in white blood cell count and red blood cell count respectively.

\section{CONCLUSIONS}

1. An anemia develops in hypothyroidism following total ablation of the normal thyroid gland for the alleviation of congestive heart failure and angina pectoris. The anemia tends toward the macrocytic hyperchromic type, being characterized by increased color index, mean corpuscular volume and mean cell diameter.

2. The anemia is at most moderate and usually only slight; it appears to be somewhat less marked in those patients operated on for angina pectoris than in those patients operated on for congestive heart failure.

3. The appearance of the anemia following operation coincides with a drop in basal metabolic rate.

4. The white blood cell count is decreased at low levels of basal metabolism following total thyroidectomy; the distribution of cell types remains normal; the platelet count is usually diminished. The evidence at hand indicates that the slight decrease in concentration of white blood cells usually present does not alter the response to infection.

5. Data obtained in this study support the concept that the anemia improves when the basal metabolic rate is increased by administration of thyroid; the administration of iron does not affect the blood findings.

6. At the levels of metabolism of approximately -25 per cent to -30 per cent usually maintained in patients after total thyroidectomy the blood changes are not great enough to give rise to symptoms of anemia. The anemia is not of sufficient degree to increase the work of the heart.

\section{BIBLIOGRAPHY}

1. Horsley, V., The thyroid gland: Its relation to the pathology of myxedema and cretinism to the question of the surgical treatment of goiter and to the general nutrition of the body. Brit. Med. J., 1885, 1,111 and 211.

2. McCullagh, E. P., and Dunlap, J. H., The Blood Picture in Hyper- and Hypothyroidism; in Crile, G., 
"Diagnosis and Treatment of Diseases of the Thyroid Gland." W. B. Saunders Co., Philadelphia, 1932, Chapter X, p. 144.

3. Blumgart, H. L., Levine, S. A., and Berlin, D. D., Congestive heart failure and angina pectoris. The therapeutic effect of thyroidectomy on patients without clinical or pathologic evidence of thyroid toxicity. Arch. Int. Med., 1933, 51, 866.

4. Blumgart, H. L., Riseman, J. E. F., Davis, D., and Berlin, D. D., Therapeutic effect of total ablation of normal thyroid on congestive heart failure and angina pectoris. III. Early results in various types of cardiovascular disease and coincident pathologic states without clinical or pathologic evidence of thyroid toxicity. Arch. Int. Med., 1933, 52, 165.

5. Blumgart, H. L., Berlin, D. D., Davis, D., Riseman, J. E. F., and Weinstein, A. A., Total ablation of thyroid in angina pectoris and congestive failure. XI. Summary of results in treating seventy-five patients during the last eighteen months. J. A. M. A., 1935, 104, 17.

6. Blumgart, H. L., and Davis, D., Hypothyroidism induced by complete removal of the normal thyroid gland in the treatment of chronic heart disease. Endocrinology, 1934, 18, 693.

7. Haden, R. L., The technic of a blood examination. J. Lab. and Clin. Med., 1932, 17, 843.

8. Van Slyke, D. D., and Neill, J. M., The determination of gases in blood and other solutions by vacuum extraction and manometric measurement. I. J. Biol. Chem., 1924, 61, 523.

9. Dameshek, W., A method for the simultaneous enumeration of blood platelets and reticulocytes, with consideration of the normal blood platelet count in men and in women. Arch. Int. Med., 1932, 50, 579.

10. Davis, D., The determination of the icterus index with capillary blood. Am. J. M. Sc., 1926, 172, 848.

11. Aub, J. C., and DuBois, E. F., Clinical calorimetry: XIX. The basal metabolism of old men. Arch. Int. Med., 1917, 19, 823.

12. Esser, Blut und Knochenmark nach Ausfall der Schilddrüsenfunktion. Deutsches Arch. f. klin. Med., 1907, 89, 576.

13. Emery, E. S., Jr., The blood in myxedema. Am. J. M. Sc., 1923, 165, 577.

14. MacKenzie, G. M., Anemia in hypothyroidism. J. A. M. A., 1926, 86, 462 .
15. Lisser, H., and Anderson, E. M., Three cases of adult myxedema in women, reported for the purpose of calling attention to their widely different symptomatology and clinical findings. Endocrinology, 1931, 15, 365.

16. Kunde, M. M., Green, M. F., and Burns, G., Blood changes in experimental hypo- and hyperthyroidism (rabbit). Am. J. Physiol., 1932, 99, 469.

17. Grollman, A., The Cardiac Output of Man in Health and Disease. Charles C. Thomas, Springfield, 1932.

18. Starr, I., Jr., Donal, J. S., Margolies, A., Shaw, R., Collins, L. H., and Gamble, C. J., Studies of the heart and circulation in disease; Estimations of basal cardiac output, metabolism, heart size, and blood pressure in 235 subjects. J. Clin. Invest., 1934, 13, 561.

19. Blumgart, H. L., Gargill, S. L., and Gilligan, D. R., Studies on the velocity of blood flow. XV. The velocity of blood flow and other aspects of the circulation in patients with "primary" and secondary anemia and in two patients with polycythemia vera. J. Clin. Invest., 1931, 9, 679.

20. Sharpe, J. C., and Bisgard, J. D., The relation of the thyroid gland to hematopoiesis. I. Experimental total thyroidectomy in the rabbit. J. Lab. and Clin. Med., 1936, 21, 347.

21. Minot, G. R., Two curable cases of anemia. I. Chronic hemolytic anemia-the "pernicious anemia of pregnancy." II. Myxedema with anemia. M. Clin. North America, 1921, 4, 1733.

22. Baldridge, C. W., and Greene, J. A., Absence of response of anemia of myxedema to liver extract. Proc. Soc. Exper. Biol. and Med., 1934, 31, 1035.

23. Means, J. H., Lerman, J., and Castle, W. B., The coexistence of myxedema and pernicious anemia. New England J. Med., 1931, 204, 243.

24. Lerman, J., and Means, J. H., Treatment of the anemia of myxedema. Endocrinology, 1932, 16, 533.

25. Stone, C. T., The occurrence of anemia in myxedema. Ann. Int. Med., 1928, 2, 215.

26. Krantz, C. I., Quoted by Means, J. H., and Richardson, E. P., Diseases of the Thyroid. Oxford Monographs on Diagnosis and Treatment, 1929, 4, 305.

27. Kocher, T., Das Blutbild bei Cachexia thyreopriva (Myxödem. Cretinoide Zustände). Arch. f. klin. Chir., 1912, 99, 280. 